УДК 821.161.2-31.09 Лис

Журба Світлана, кандидат філологічних наук, доцент, доцент кафедри української та світової літератури Криворізький державний педагогічний університет

\title{
РЕІНТЕРПРЕТАЦІЯ ІСТОРІї У РОМАНАХ ВОЛОДИМИРА ЛИСА
}

\begin{abstract}
У статті на матеріалі романів «Століттл Якова», «Соло для Соломї̈», «Краӥна гіркої ніжності» Володимира Лиса простежено особливості художнъої реінтерпретації маловідомих сторінок історіӥ Волині XX століття. Акцентовано на періоді репресій 30-x років, долі дітей «ворогів народу» та повстансъкому русі УПА. Вказано на руйнування канону щодо добровілъного прийняття селянами радянсъкої влади на Волині. Простежено художні шляхи «ревізї̈ історії» у романістиці писъменника. Альтернативна історія епохи оприявлена через приватний досвід героїв. Історична достовірність маркована датами, просторовими координатами, реальними постатями доби. Нехрестоматійне зображення дійсності дозволило автору вказати на плюралістичність історичної правди.
\end{abstract}

Ключові слова: реінтерпретація історї̈, репресї̈, приватна історія, діти «ворогів народу», «ревізія історії», реалї епохи, рух УПА.

\section{Zhurba S. Reinterpretation of history in the of Volodymyr Lys.}

The article deals with the features of artistic reinterpretation of the littleknown pages of the history of Volyn in the 20th century on the material of the novels «Jacob's Age», «Solo for Salome», «Country of Bitter Tenderness» by Volodymyr Lys. Through the fate of the characters of such novels as the «Jacob's Age», «Solo for Salome», the socio-political life of Ukraine from the 1920s until independence was conceived; the mood of the population in certain periods of history is outlined; ordinary Ukrainians in times of social change are depicted. The real pictures of epoch are reflected in the fate of characters of the novel "Country of Bitter Tenderness».

It is focused on the period of repression of the 1930s, as well as on the fate of children of the "enemies of the people» and the insurgent movement of the Ukrainian Insurgent Army, modern events in the Independence Square. Outlining the major milestones in the history of the state and character of the novels Volodymyr Lys resorts to artistic fiction in depicting the private life of his characters' private life, romanticizing love stories. The destruction of the canon concerning the voluntary acceptance of the Soviet authorities in Volyn by the peasants was pointed out. The artistic ways of the «revision of history» in the novels of the writer are traced. An alternative history of the era is revealed through the personal experience of characters. Emphasizing on the personal history of the characters of the works, the author points to the values of Ukrainians: such as family traditions, work on earth. Historical accuracy is marked by dates, spatial coordinates, and historic personalities 
38 Літератури світу: поетика, ментальність і духовність. 2020. Bип.14

of the day. The non-chrestomathy depiction of reality allowed the author to point to the pluralistic nature of historical truth. The vitality of the reproduction of events, the fate of the inhabitants of Volyn in the novels is achieved through the synthesis of historical and artistic truth.

Key words: reinterpretation of history, repression, private history, children of «enemies of the people», «revision of history», realities of the era, UIA movement.

Постановка проблеми. У сучасному українському літературознавстві історична тема є актуальною з огляду на суспільні події сьогодення, так і в аспекті осмислення подій минулого засобами художнього мистецтва. Слушною є думка М. Ільницького щодо звернення до історичної теми у вітчизняній літературі, реалістичного відтворення подій, адже «наша література дозріла до художнъого відображення історії духовної, історії мислячої, історї̈ ідей. Черпати з криниці минулого досвіду ту иілющу воду, яка оздоровлюе й нашого сучасника, найперше завдання» [2, с.95].

Художня інтерпретація історії у творах сучасних українських письменників «Фелікс Австрія» Софії Андрухович, «Танго смерті» Юрія Винничука, «Ворошиловград» Сергія Жадана, «Червоний» Андрія Кокотюхи, «Настане день, закінчиться війна» Петра Лущика, «Солодка Даруся» Марії Матіос, «Залишенець. Чорний ворон», «Маруся» Володимира Шкляра дозволяє вказати на «життєподібність» та оприявлена через співвідношення дії та історичних орієнтирів, повчальність для наступних поколінь. Тема голодомору 1933 року, сталінських репресій 30-х років, подій Другої світової війни, зокрема національного руху ОУН-УПА у літературі були табуйованими. Завісу відкрили твори «Останній герой», «Криївка» Олександра Вільчинського, «Танець білої тополі», «Сірий янгол» Надії Гуменюк, «Країна гіркої ніжності», «Століття Якова», «Соло для Соломії Володимира Лиса, «Забудь-ріка» братів Капранових, «Музей покинутих секретів» Оксани Забужко. Детально змальовано життя політв'язнів радянського режиму, їх перебування у концтаборах та спецпоселеннях, зокрема Кенгірське повстання у романі Лесі Романчук «Лицарі любові та надії». Твір Лесі Романчук побудований на реальному матеріалі, а прототипами героїв стали батьки письменниці, засуджені за участь в УПА сталінським режимом. Метод історичної біографістики дозволив письменникам правдиво відтворити життєві обставини родин репресованих.

Романи Володимира Лиса продовжують традицію західноукраїнської літератури щодо переосмислення непростої людської долі поліщуків у контексті національної історії. Динамічність розгортання сюжету, 
змалювання культури, побуту та реалій доби, мелодраматизм, що поєднується з зображення народного життя, визначають своєрідність художньої нарації творів письменника.

Аналіз останніх досліджень та публікацій. Переосмислення розвитку української історичної романістики, питання історичної правди і художнього вимислу в прозі розглянуто у дослідженнях С. Андрусів, Є. Барана, Н. Горбач, М. Ільницького, Б. Мельничука, М. Сиротюка та ін. Творчість Володимира Лиса у сучасному літературознавстві стала предметом досліджень В. Агеєвої, С. Бородіци, О. Забужко, О. Клименко, Я. Поліщука, Т. Прохаська, Роксоляни Свято, Л. Скорини, Т. Хом'як, Л. Якимчук та інших. Однак, проблема нового прочитання української історії, переосмислення її трагічних сторінок у романах Володимира Лиса малодосліджена, що й визначає актуальність роботи.

Мета й завдання дослідження. На матеріалі романів Володимира Лиса «Століття Якова», «Соло для Соломії», «Країна гіркої ніжності» дослідити художню реінтерпретацію історії, зокрема періоду репресій та руху опору УПА, вказати на історію/вимисел у творі, простежити художні шляхи «ревізії історії» у романістиці письменника.

Виклад основного матеріалу дослідження. Нехрестоматійний погляд на історію Полісся та України в цілому у ХХ столітті, правдиве зображення фактів історії, відтворення особистого життя людини на тлі суспільно-політичних реалій, осмислення шляхів розвитку нації простежуємо у романах Володимира Лиса «Країна гіркої ніжності», «Століття Якова», «Соло для Соломії. Реінтерпретація історії у творах письменника спрямована на художню ретроспекцію подій минулого століття, осмислення реципієнтом певних обставин в житті українців, руйнування канону щодо повного прийняття радянської влади на Західній Україні, цілковитої покори й «щирого вітання» нового життя селянами-поліщуками у часи тоталітарного режиму Сталіна, репресій більшовицької влади на східноукраїнських та західноукраїнських землях, знищення вояків УПА. Топоси і локуси романних історій розставляють акценти у долях звичайних, а разом з тих непересічних українців - персонажів творів Володимира Лиса. Життя мешканців села Загоряни складає сюжетну канву романів «Століття Якова» та «Соло для Соломії. Невелике село на Поліссі, наповнене радісними та трагічними суспільними подіями, стає мікромоделлю держави. 3 Луцьком пов'язана доля героїнь твору «Країна гіркої ніжності». 
Реалії історичного минулого у творах як пазл складають правдиву картину історії України, виокремлюючи перш за все трагічні сторінки. Журналістська діяльність Володимира Лиса сприяла знайомству 3 цікавими людьми Волині, а розповіді рідних, знайомих, звичайних селян-поліщуків лягли в основу історій для рубрики «Невигадані історії» та стали джерелами романів митця.

У центрі творів автора - історична реконструкція свідомості людини, яка жила у добу тоталітарного режиму і живе сьогодні, побуту, приватного життя українців, їх звичаїв, культури. Не зважаючи на тиск системи, намагання знищити духовно особистість, принизити, герої романів Володимира Лиса вистоюють, залишаються морально стійкими і не втрачають власної гідності, людського обличчя.

Приватна історія героїв та дійсність у романах детермінована спогадами, «голосом» Якова Меха («Століття Якова»), Дездраперми Снігурець та її дочки Віталіни («Країна гіркої ніжності»). Напередодні свого століття осмислює життя Яків Мех, із глибин пам'яті витягує найяскравіші історії, що вплинули на становлення та формування особистості. Хвороба Віталіни сприяє переосмисленню власного життя, стає відправною точкою для спогадів самої жінки та її матері про ті події, які вплинули на розвиток особистості, стали переломними у житті. Ретроспективний характер оповіді у романах дозволяє говорити про взаємопроникнення часів, увиразнення художньої картини дійсності. Принцип «зворотної» та «наступної» хронології творить змістову єдність твору, об'єднуючи фрагменти життєвих історій персонажів. Відповідно до канонів історичного жанру та сімейної саги автор творить «альтернативну версію минулого, оперту на приватний біографічний досвід одного героя, а також принагідно - i його оточення» [6, с. 87]. Історії чоловіка та жінки у романах постають як вічна динаміка «буттяв-історії».

У романі «Соло для Соломії» хронологічна послідовність життя Соломії Рощук співвідноситься з історією України упродовж ХХ століття. Життєпис героїні помережаний радісними та трагічними особистими історіями та осмисленням нелегкої долі українського народу у період тоталітаризму. Історичний хронотоп у романі чітко прописаний: життя Соломії вимірюється з року її народження - 1925 і до старості: на момент завершення твору жінці виповнюється сімдесят сім років. Через долю Соломії осмислено суспільно-політичне життя України від 20-х років XX століття аж до здобуття незалежності, окреслено зріз настроїв населення у певні періоди історії, змальовано звичайних українців у часи суспільних змін. «Історія роду, що проростає в історію народу» - 
так визначив жанрову своєрідність роману «Соло для Соломії» сам автор.

Історична достовірність творів маркована точними датами та просторовими координатами, історичними постатями, щоправда, реальні історичні особи у романах згадуються лише побіжно. Тоталітарний режим СРСР часів правління Сталіна у романі «Країна гіркої ніжності» детермінований політичними репресіями 30 -х років $\mathrm{XX}$ століття, виявом «ворогів народу», зображенням будинків-інтернатів для дітей «ворогів», перевихованням майбутнього покоління відповідно до настанов партії - доноси, публічне зречення батьків, втрата родових цінностей, руйнування психіки дітей, доведення їх до самогубства тощо. Такою дитиною є Даздраперма Снігурець, дочка «ворогів народу», через образ якої оприявлено складні та трагічні події репресій періоду CPCP: батька арештували за доносом його друга (про це аж на схилі літ дізнається жінка), згодом нкаведисти забрали і маму, а дівчинку відправили у спеціальний будинок для дітей «ворогів народу». Згадує Даза тяжке життя у дитбудинку - приниження дітей вчителями та вихователями, погані умови проживання (сорок дівчаток в одній кімнаті, де тхнуло хлоркою, пилюкою, потом, брудною постільною білизною і, мишачим послідом [3, с.96]), знущання одних вихованців над іншими. Акліматизуватися дітям із благополучних сімей у різношерстому колективі було досить важко. Дівчинка під впливом середовища почувається зрадженою батьками й відрікається від них, змінюючи прізвище на Рубцова. Її подружка Соня Кудрявченко не відмовляється від батьків-ворогів, тому зазнає зневажливого ставлення від персоналу та дітей. Ім'я Дази марковане лексикою періоду становлення радянської влади й російською скорочено означає «Да здравствует первое мая». Стиль епохи відбився на долях сотень дітей, яким в честь вождів пролетаріату та нових ідей давали «вичурні» імена: хлопчиків називали Кімами (скорочено Комуністичний інтернаціонал молоді), Віленами (Володимир Ілліч Ленін), дівчаток - Електринами, Інтернами, Сталінами, Тракторинами.

Сталінська політика сімейного заручництва була спрямована на дискримінацію тисячі родин: дружини і діти не допускалися до відповідальних постів, до навчання у вищих школах. У такій ситуації опинилася сім'я арештованого за «злочинні дії» проти влади заступника наркома харчової промисловості Романа Снігурця з роману «Країна гіркої ніжності». Його дружину теж було засуджено і вона померла у концтаборі, а дочка, врятувавшись під час бомбардування у перші роки війни, знайшла прихисток у самотньої бабусі в маленькому 
містечку на Полтавщині. Після війни дівчина змушена змінити прізвище та ім'я на Любов Лук'янченко, щоб вижити і отримати професію, адже «сини і дочки заарештованих завжди залишалися під підозрою» [1, с. 24].

Хронометром доби у романах Володимира Лиса $є$ суспільнополітичні події на Волині минулого століття. Письменник виокремлює час 30-50-х років, який збігається з періодом становлення особистості, роками юності та зрілості Якова Меха, Соломії Рощук і Даздраперми Снігурець (у волинський період життя - Люба Лук'янченко) й трагічними сторінками історії країни. Реалії епохи безпосередньо відбилися у долі кожного з героїв. Яків Мех бере участь у Другій світовій війні, потрапляе у концтабір, воює на боці поляків та совєтів. $\mathrm{y}$ «Столітті Якова» постає метафоричний образ війни як «виверження стихійного зла, тотальної катастрофи» [6, с.90-91], некерованої стихії: «Велика війна гримить над світом. Повзе через кордони, моря $і$ річки, гори $і$ ліси, $і$ ніяка сила - ні Божа, ні людсъка - не годна ї̈ спинити» [5, с. 140]; як великої м'ясорубки, в якій людське життя не має значення: «За Родіну, за Сталіна через мінне поле гнали» рядових солдатів, «итабелями трупів укладали» [5, с. 178]. У критичній ситуації, вважає Н. Яременко, аналізуючи тему війни у творах Олександра Довженка, «опорою була віра й віковічні підвалини народної моралі» [8, с. 289]. Тому християнин Яків Мех, перебуваючи у концтаборі, звертається до Бога та свого небесного покровителя i, ніби незримо й «наяву разом з ним везе тачку з рудою aпостол Яків» [5, с. 161]. У період найдраматичніших суспільних катаклізмів героєві доводиться зазнати і втрати власної родини. За допомогу «бульбашам», нкаведисти, перевдягнуті бандерівцями, розстріляли його дружину і двох дочок. Автор акцентує на підступних звірствах більшовиків, знищенні всього українського, нагнітанні страху на селян. Власне страх за сім'ю змушує Якова та його дочку Параску дати неправдиві свідчення на судовому процесі. Інстинкт самозбереження у «межовій ситуації», якою $є$ війна чи післявоєнний період, «універсальний і детермінований біологічною природою людини, однак механізми захисту індивідуума в критичній ситуації повною мірою залежать від соціокультурних параметрів» [8, с. 285]. Реальна історія у романі, на відміну від хрестоматійної, експлікує приватну історію, бо українські селяни живуть цінностями родини та праці на землі, дотримуються заповідей своїх прадідів, пристосовуючись до зміни влади. Вибудовуючи образ історичної доби та вказуючи на місце в ній звичайного селянина, автор проводить паралелі між минулим 
і сучасним, романтизуе та домислює життєву історію «маленької людини», концентрує увагу на яскравій деталі.

Реінтерпретація історичної теми у романах «Століття Якова» та «Соло для Соломії базується на осмисленні маловідомих сторінок історії Волині, Галичини. «Ревізія історї» (Я. Поліщук) е спробою автора відкрити «завісу», витягнути із забуття ті факти, які селяни старалися не згадувати, зважаючи на закони нової влади. Визволення українських земель від фашистських загарбників супроводжувалося й боротьбою нкаведистів з УПА на західноукраїнських землях. Жертвою цього протистояння стає коханий Соломії Петро (псевдо Ярема), який не вийшов з лісу, а навесні жінка «зрозуміла, що правильно зробив. Хоч перед тим $i$ вивезли сім'ю в Сибір. Бо ж тих, хто вийшов, у тюрму посадили або ж змусили за колишніми побратимами ганятися. Ци в якісь страшнї спецкоманди, про які казали в селі, що під видом вкраїнсъких партизан людей вбивають, послали» [4, с. 155]. Національний рух на Західній Україні був вороже сприйнятий радянською владою, та й на східній частині країни 3 обережністю ставилися до «західняків». Зокрема, херсонський тракторист Григорій обміняв Соломію на звання героя соціалістичної праці, бо брат застерігав, що жінка-западенка, «невідомо, що там у неї, родня яка, мо', в бандерах були хто, то, диви, й на тебе тінь упаде, можуть $i$ героя не дати, та вообще з тими западними ліпше не знатися» $[4$, с. 358]. У романі письменник показує як суспільні процеси проникають в особисте життя персонажів: насильницьке записування у колгосп, арешти селян за «шкіднищтво щодо майбутнъого колгоспного товару» [4, с. 196], переслідування та знищення вояків УПА, вивезення українців до Сибіру за співпрацю з УПА.

У «Країні гіркої ніжності» Даза після закінчення медичного училища отримує направлення на Волинь. Там вона випадково знайомиться і допомагає повстанцям: передає медикаменти, рятує породіллю у криївці. Дівчина розуміє, що за співпрацю з бандерівцями їі можуть арештувати, проте витягує із-під завалів схрону «дівчинку, немовля, що вижсло в страшній круговерті, страшному спалаху cмерті» [3, с. 172], а потім всиновлює дитину вояка на псевдо Карий (ним виявився засуджений за участь у повстанському русі Матвій Білітюк). Мешканці села здогадуються про їі співпрацю, але не видають, адже майже в кожного родичі були членами УПА. Даза згадує й про репресії західноукраїнських сімей за співучасть або допомогу бандерівцям: «Через місяць їх вантажили в "теплушки", вивозили кудись на схід» [3, с. 154], а в селі «стояло кілька порожніх 
хат вивезенців - куркульсъких сімей $i$ “бандопособніков"» [3, с. 155]. Політична діяльність селян, релігійні переконання чи «злочині дії» проти радянської влади (знищення реманенту чи вирізування худоби, яку не хотіли віддавати в колгосп) на західноукраїнських землях стали інструментом у руках радянських правоохоронних органів проти «ворогів радянської влади». Покарання певного прошарку селянських родин використовувалось з метою освоєння земель Сибіру (про це говорить Володимир Лис у романі «Століття Якова»), залякування хліборобів, демонстрування «перспектив» їх життя за відмову вступати до колгоспу чи підтримку політики радянської влади на селі.

Реінтерпретація історії автором у романах відкриває ті факти, які не є хрестоматійними й не відомі пересічному читачу, адже, на думку Я. Поліщука, погляд Володимира Лиса «загалом відповідає духові нашої переломної доби, котра культивує руйнування однозначного образу минувшини, а також забезпечує просування "малих наративів" та плюральності історичної правди» [6, с.93]. Подібне зустрічаємо у творах «Солодка Даруся» Марії Матіос, «Лицарі любові і надії» Лесі Романчук, в яких руйнується стереотип «єдиної батьківщини» $\mathrm{i}$ «братнього народу»: «nів України етапами до Сибіру везутъ» [7, с. 78], а засуджених українців принижують, поставивши навколішки, бо «такий спосіб більше полюбляють у Росї̈ [7, с. 73]. У романі Лесі Романчук молоді галичанки, які допомагали повстанцям, не розуміють, чому їх засуджено, названо «бандерівками», адже «ми ж були не проти них (росіян - С.ЖК.), ми тільки хотіли жити на свойй землі за нашими звичаями! Ми не приїхали їм запроваджувати свої закони, свою мову, свої тюрми, а вони до нас! Ми ж тільки не хотіли неволі!» [7, с. 104]. Головні принципи права у тоталітарному режимі як «презумпція невинуватості, співмірність злочину та покарання» ігнорувалися, «оскільки насильство застосовувалося до тих, хто ніяких законів не порушував: до родичів обвинувачених або вже покараних» $[1$, c. 15]. Засуджені пізніше зрозуміють, що дуже легко стати в'язнем у країні суцільних підозр.

Українська історія у романі «Соло для Соломії» постає як національний світ, що випробовується радянською системою. Жителі Загорян живуть своїми радощами і болями, надією та сподіваннями, вітають перемогу над фашистами, проте їх радість не мала нічого спільного із торжеством прихильників радянської влади, які послуговуються ідеологією тоталітарної системи: «казали, що Перемога над ворогом досягнута під мудрим керівничтвом вождя товариша Сталіна, що буде тепер нове, щасливе й мирне життя, за яке 
поклали голови в боях сорок двоє загорениів» [4, с. 159]. Інтерпретуючи історичні події, розкриваючи внутрішні переживання персонажів твору, автор звертається до національного питання у колишньому СРСР. Авторське потрактування сприйняття поліщуками совєтської влади експліковано через підміну національних ідей більшовицькими: «Поліщуки придивлялися, принюхувалися, як у селі казали, до нової влади, котру минулої осені вітали при в'їзді до Загорен аркою, уквітчаною червоними $і$ жовто-блакитними прапорами, флагами по-їхнвому. Але через рік про жовто-блакитний колір і згадувати ни мона було, казали, вражеський, буржуазний, ци ще якийсъ, теї совети напридумували слів, що язик поламається» [4, с. 54]. Радянська влада прагнула навернути волинян до «нового життя», користуючись при цьому облудними гаслами, спекулюючи на національному питанні, згадуючи Тараса Шевченка та прикриваючись іменами козацьких ватажків.

Організація, чи вірніше, відновлення колгоспів після війни будувалося на заманюванні селян обіцянками, насправді ж уповноважені діяли насильницькими методами - розкуркулювали, забирали збіжжя, речі, а незгодних висилали до Сибіру: «Ще в сорок шостім ожило майже забуте слово - колхоз. Хоч було й друге, більш украӥнсъке - колгосп. Але так казав мало хто. Спершу, як $i$ в сороковім рочі, в колхоз-колгосп подалися найбідніші майже добровільно, з вискоком, як казали в селі. Решту взялись агітувати, умовляти, натякати на можливі кари, а то й відверто погрожувати. Дядъки чухали лоби й потилиці - не хотілося з нажитим поліщуцьким горбом сяким-таким добром розлучатися, а їхні жінки крадъкома, а то й не криючисъ, витирали слъози й шептали давні замовляння од наглої напасті» [4, с. 195]. Письменник відкидає хрестоматійне добровільне записування західноукраїнських селян у колективні господарства, порівнюе методи більшовиків із фашистськими: «Незвані гості, котрі були хужіші не тико од татарви, а 亡̆ од саранчі твмяно-зеленої, котра недавно двічі прокотилася селом, зрештою забиралися з хати, добившись обіиянок у колгосп вступити, а то й виведених каракулями заяв ии підписухрестика на заяві, загодя заготовленій [4, с. 195]. Соломія згадує, що багато хат залишилися порожніми або використовувалися радянською владою під комори, склади після виселення за опір колективізації в Сибір тих, хто не підкорився. Медсестра Люба Лук'янченко (Даза) теж згадуе про організацію колгоспу «до якого заганяли селян» [3, с. 99] у післявоєнний час. Володимир Лис подає у «Соло 
46 Літератури світу: поетика, ментальність і духовність. 2020. Bип.14

для Соломії» маловідомі факти історії часів т.зв. «хрущовської відлиги»: «У хрущовсъкі часи на Волині була демонстрачія проти закриття Свято-Троӥцького собору у Луцьку ( $i$ його відкрили на другий денъ), локальні виступи проти закриття церков у селах, короткий бунт проти приєднання волинсъкого села Княжого до Львівсъкої області» [4, с. 309].

У романі «Соло для Соломії» автор зображає нелегку працю селян в колгоспі (сіяли і збирали кок-сагиз, який різав руки), роботу на шахтах (брат Василько їде на заробітки на Донбас і отримує травму), короткими штрихами передає долю брата-емігранта Тараса, який тільки в роки здобуття Україною незалежності обізвався до родичів - написав листа, а потім і приїхав в гості (боявся раніше нашкодити рідним, бо за радянськими законами вважався дезертиром і зрадником).

Сучасні події в історії нашої держави у романі «Країна гіркої ніжності» автор змальовує через образ внучки Даздраперми Снігурець Олесі. Дівчина підтримує протестувальників на Майдані Незалежності під час помаранчевої революції. Проте і цей історичний період переданий через приватне життя Олесі - саме на Майдані вона закохалася в луцького протестувальника Ярослава.

Володимир Лис у романах «Століття Якова», «Соло для Соломії», «Країна гіркої ніжності», змальовуючи реальну історію держави, вдається до художнього вимислу, зображуючи приватне життя персонажів, романтизуючи історії кохання.

Висновки та перспективи подальших наукових розвідок. Художня інтерпретація історії України упродовж ХX століття, змалювання трагічних подій в долі народу, життя волинян за часів Польщі, Німеччини, радянської України у романах «Століття Якова», «Соло для Соломії», «Країна гіркої ніжності» дозволила автору не лише відтворити найтиповіші конфлікти доби через проникнення зовнішньої дійсності в естетичну сутність людського характеру, а й реінтерпретувати історію, відтворити забуті її сторінки. Життєподібність відтворення подій, долі мешканців Волині досягається завдяки синтезу історичної правди та правди художньої. Інтерпретуючи історичні факти відповідно до ідейного змісту твору, автор розкриває світогляд персонажів, акцентує увагу на збереженні національної пам'яті. Перспективою подальших досліджень є особливості жанровостильових трансформацій романів Володимира Лиса. 


\section{Література}

1. Вронська Т. В. Репресії проти родин «ворогів народу» в Україні: ідеологія та практика (1917-1953 рр.) : автореф. дис. ... доктора істор. наук : 07.00.01 / Інститут історії України НАН України. Київ, 2009. $42 \mathrm{c}$.

2. Ільницький М. У фокусі віддзеркалень: Статті. Портрети. Спогади. Львів : Львівський національний університет імені Івана Франка, 2005. $552 \mathrm{c}$.

3. Лис В. Країна гіркої ніжності. Роман. Харків, 2015. 368 с.

4. Лис В. Соло для Соломії : роман / передм. Т. Прохаська. Харків: Книжковий Клуб «Клуб Сімейного Дозвілля», 2013. 368 с.

5. Лис В. Століття Якова. Харків : Книжковий Клуб «Клуб Сімейного Дозвілля», 2012. $240 \mathrm{c.}$

6. Поліщук Я. РЕвізї̈ пам'яті: літературна критика. Луцьк : ПВД «Твердиня», 2011. 216 с.

7. Романчук Л. Лицарі любові і надії. Тернопіль : Богдан. 2010. 672 с.

8. Яременко Н. Вербалізація феномена страху у прозі О. П. Довженка періоду війни. Літератури світу: поетика, ментальність і духовність. Збірник наукових праць. Кривий Ріг, 2014. Вип. 3. С. 278-290. 